\title{
ASSESSMENT OF THE CASTING POSITION FACTOR IN REINFORCED CONCRETE ELEMENTS IN VIEW OF EXPERIMENTAL STUDIES
}

\author{
Piotr Dybet ${ }^{1}$, Kazimierz FurtaK $^{2}$
}

\begin{abstract}
The paper presents the results of experimental investigations performed by the authors on the casting position factor. It was proved that at the height of reinforced concrete elements there are different bond conditions. Moreover, the bond depends on concrete mechanical properties, element height as well as concrete mix composition and consistency. The experiments also showed the advisability of determining the casting position factor separately for bars from normal concrete and those from high-performance concrete (HPC). The analysis of investigation results has shown that "good" bond conditions are a relative concept and depend on, among other things, element height. The higher the element the better the concrete to lower bars bond. Consequently, elements of considerable height (higher than $600 \mathrm{~mm}$ ) demonstrate a bigger difference between concrete to upper bars bond and concrete to lower bars bond.
\end{abstract}

Keywords: bond, casting position, anchorage length, high-performance concrete

\section{INTRODUCTION}

The development of reinforced concrete and prestressed structures has resulted in the application of various types of concrete. Modification of concrete mechanical parameters affects the conditions of concrete - reinforcement cooperation, which is fundamental in reinforced concrete as a structural material. This leads to problems of the lack of clear guidelines related to determination of reinforcing bars anchorage length, particularly bars made from high-performance concretes.

The issues connected with concrete-reinforcing bars bond are a result of studies primarily on elements made from normal concretes [19]. However, it is commonly believed that the result of tests performed on normal concrete cannot be transferred directly to high-performance concretes $[11,13,15]$ This is why it is necessary to undertake further experiments on the phenomenon of bonding.

1 Department of Geomechanics, Civil Engineering and Geotechnics, AGH University of Science and Technology, Poland, e-mail: dybel@agh.edu.pl

Corresponding author, Katedra Geomechaniki, Budownictwa i Geotechniki Al. Mickiewicza 30, 30-059 Kraków

2 Department of Building Bridges and Tunnels, Cracow University of Technology, Poland, e-mail: kfurtak@pk.edu.pl 
The objective of the article is to assess the effect of various factors on concrete-reinforcing bars bond, in particular to determine the bond of anchorage length. To facilitate the interpretation of studies results and recommendations all test results will be discussed in terms of a casting position factor, witch is define as a factor for multiplying the anchorage length of a "bottom bar" to obtain the anchorage length of a bar located at any height in the fresh concrete.

\section{Previous investigations}

From the research $[16,17,18]$ it follows that an increase of the distance of reinforcing bars from the formwork bottom (large depth of fresh concrete below the reinforcing bar) leads to a reduction bond strength. This effect called the "top bar effect", also depends on the composition and concrete slump the manner of its consolidation and position of the reinforcing bars during concreting.

Based on testes carried out by Clark [10], the top bar effect was introduced into the ACI Building Code in 1951 [1], in the form of allowable bond stresses at working loads. The allowable bond stress for a top-cast bar was 0.7 times the allowable stress for a bottom-cast bar.

The 1971 ACI Building Code [2] replaced the earlier bond stress calculation with an expression for anchorage length. In this code, the top bar effect is accounted for by multiplying the calculated anchorage length by factor of 1,4 , which corresponds to the top bar bond stress reduction factor of 0,7 from the previous ACI Building Codes.

As a result of experiments performed by researchers in ACI Committee 4081979 [6] a change of the upper casting position factor to the value of 1,3 was proposed. The studies Jaunty et al. 1988 resulted in introducing the proposed changes in the 1989 ACI Building Code [4]. This factor is currently used for reinforced concrete design. The current code specify that the basic anchorage length shall be multiplied by a casting position factor when more than $300 \mathrm{~mm}$ of concrete is cast below the bar.

In Eurocode 2 [12] and Model Code 2010 [14] recommendations the factor for bond conditions and the position of the bar during concreting is recommended. The value of this factor is equal to 0,7 when "poor" conditions are obtained. This corresponds to increasing the anchorage length by $43 \%$.

The results of research Luke et al. [18] show that the value of the top bar bond stress reduction factor adopted in ACI Building Code 1977 [3] for high slump concrete mixes and adequately high element is definitely underestimated (Figure 1).

On the basis of the same experimental studies it may also be stated that in the bars placed parallel to concrete placement direction at an adequately large height of the element the loss of bond is found to be $30 \%$. In recommendations were formulated for the selection of the casting position factor depending on reinforcement position in fresh concrete mix and its slump. The recommended values of the factor have been shown in Figure 2. 


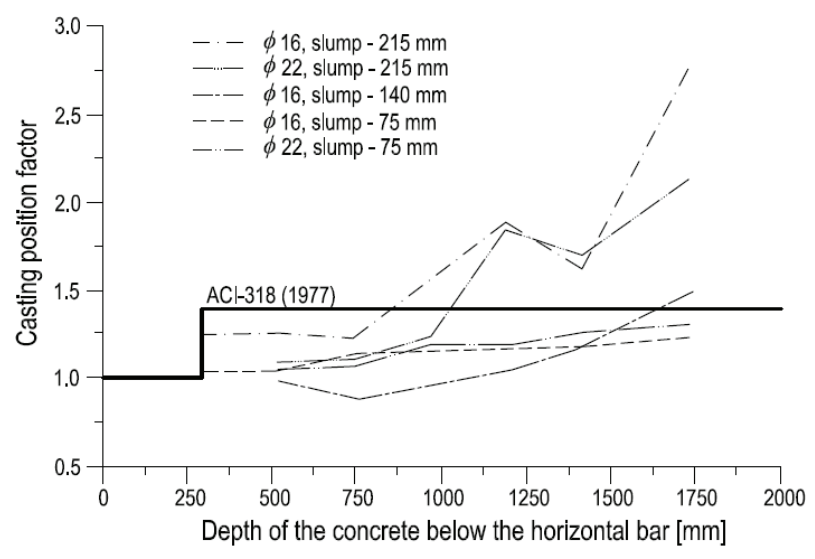

Fig. 1. Casting position factor vs. bar height [18]

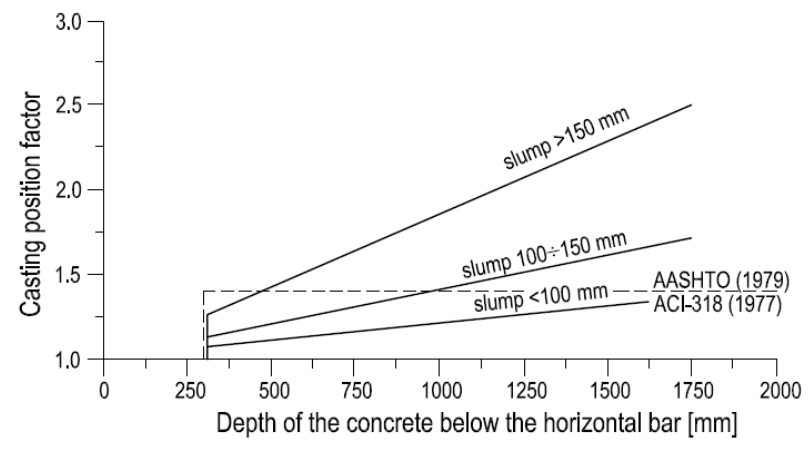

Fig. 2. Recommended casting position factor for all ranges of slump investigated [18]

Experimental investigations have shown Brettmann et al. $[7,8]$ that the reduction in bond of upper bars depends on the height of the reinforced concrete element. In these studies elements of 250, 450 and $1000 \mathrm{~mm}$ in height were tested. The difference in the values of bond stresses of the upper bars between the highest and lowest element ranged from 8 to $18 \%$ depending on the concrete slump. In the quoted studies the reduction of bond stresses between upper and lower bars for a given height of the element was higher than the difference in bond of the upper bars located in particular types of elements. These results prove that the zones of favorable bond conditions in standard recommendations ACI Building Code are arbitrary and are not justified in the results of experimental investigation. 
2. RANGE AND MANNER OF CONDUCTING THE INVESTIGATIONS BY THE AUTHORS

\subsection{RANGE OF INVESTIGATIONS}

The aim of the investigations was to determine the value of ultimate stresses of highperformance concrete bond to reinforcing bars with different concrete composition as well as bars location and orientation relative to direction of concreting.

In the frame of a larger research project experimental models were developed which differ in:

- height of reinforcing bars location,

- bars orientation relative to concrete placement direction,

- concrete mix composition and consistency class.

The bond experiments were carried out in a pull-out test recommended by RILEM [20]. Additionally, standard concrete compressive strength tests were run as well as tensile strength tests (in splitting tests). Also concrete modulus of elasticity was determined. All the experiments were performed after 28 days of concrete curing in laboratory conditions.

\subsection{Materials USED IN EXPERIMENTS}

The experiments were performed on six different mixes of high-performance concrete, whose variable parameters were the content of silica fume and superplasticizer. The concrete mixes were made with the addition of silica fume (SF) in the amount of 0 , 5 and $10 \%$ of the cement mass in two consistency classes, S2 and S4. Table 1 and 2 shows composition by mass of proposed HPC mixes and details of concrete mixes, respectively.

Table 1.

Composition by mass of proposed HPC mixes

\begin{tabular}{|c|c|c|c|c|c|c|}
\hline \multirow{2}{*}{$\begin{array}{c}\text { Composition } \\
{\left[\mathrm{kg} / \mathrm{m}^{3}\right]}\end{array}$} & \multicolumn{7}{|c|}{ Recipe denotation } \\
\cline { 2 - 7 } & A-0 & A-5 & A-10 & B-0 & B-5 & B-10 \\
\hline Cement CEM I 42.5R & 500 & 476 & 455 & 500 & 476 & 455 \\
\hline Water & 158,5 & 157,0 & 156,5 & 157,0 & 156,0 & 155,0 \\
\hline River sand 0/2 mm & 668 & 665 & 662 & 668 & 665 & 662 \\
\hline Basalt drid 2/8 mm & 659 & 655 & 653 & 659 & 655 & 653 \\
\hline Basalt drid 8/16 mm & 582 & 580 & 577 & 582 & 580 & 577 \\
\hline Silica fume (SF) & 0,0 & 24,0 & 45,0 & 0,0 & 24,0 & 45,0 \\
\hline Superplasticizer (SP) & 2,50 & 4,76 & 5,45 & 5,00 & 6,81 & 7,73 \\
\hline
\end{tabular}


Table 2.

Details of concrete mixes

\begin{tabular}{|c|c|c|c|c|c|c|c|c|c|}
\hline Mix symbol & $\begin{array}{c}\text { Slump } \\
{[\mathrm{cm}]}\end{array}$ & $\begin{array}{c}f_{c, c y l} \\
{[\mathrm{MPa}]}\end{array}$ & $\begin{array}{c}v \\
{[\%]}\end{array}$ & $\begin{array}{c}f_{c, \text { cube }} \\
{[\mathrm{MPa}]}\end{array}$ & $\begin{array}{c}v \\
{[\%]}\end{array}$ & $\begin{array}{c}f_{c t, s p} \\
{[\mathrm{MPa}]}\end{array}$ & $\begin{array}{c}v \\
{[\%]}\end{array}$ & $\begin{array}{c}E_{c m} \\
{[\mathrm{GPa}]}\end{array}$ & $\begin{array}{c}v \\
{[\%]}\end{array}$ \\
\hline A-0 & 6,0 & 80,0 & 2,0 & 84,9 & 3,9 & 5,6 & 2,1 & 47,9 & 2,5 \\
\hline A-5 & 6,5 & 84,4 & 5,2 & 89,6 & 4,2 & 5,5 & 9,2 & 49,0 & 1,2 \\
\hline A-10 & 8,0 & 82,3 & 3,5 & 87,0 & 3,8 & 5,5 & 4,5 & 46,6 & 4,2 \\
\hline B-0 & 18,0 & 81,0 & 1,6 & 87,2 & 1,6 & 5,7 & 4,2 & 46,9 & 1,7 \\
\hline B-5 & 20,0 & 92,6 & 3,4 & 95,4 & 2,7 & 5,9 & 5,1 & 50,8 & 4,1 \\
\hline B-10 & 21,0 & 90,7 & 1,8 & 91,1 & 4,5 & 6,4 & 5,3 & 49,6 & 1,6 \\
\hline
\end{tabular}

For tests ribbed reinforcing bars (RB500W) were used. One reinforcing bar diameter of the value of $16 \mathrm{~mm}$ was used representative for the so-called mean diameters $(10 \div 20 \mathrm{~mm})$.

\subsection{TEST SPECIMENS}

The tests were performed on three elements that differed in the height and reinforcement orientation relative to concrete placement direction. Element I was size-wise compatible with the specimen recommended by RILEM $(10 \phi \times 10 \phi)$, and the reinforcing bar was oriented vertically during concrete placement. The other two elements were designed so that the bars were placed horizontally and their height was the multiple of the basic RILEM module. Element II was composed of three basic modules while element of type III of six. After 21 days the elements were cut into elementary specimens. A schematic view of the test specimens has been shown in Figure 3.
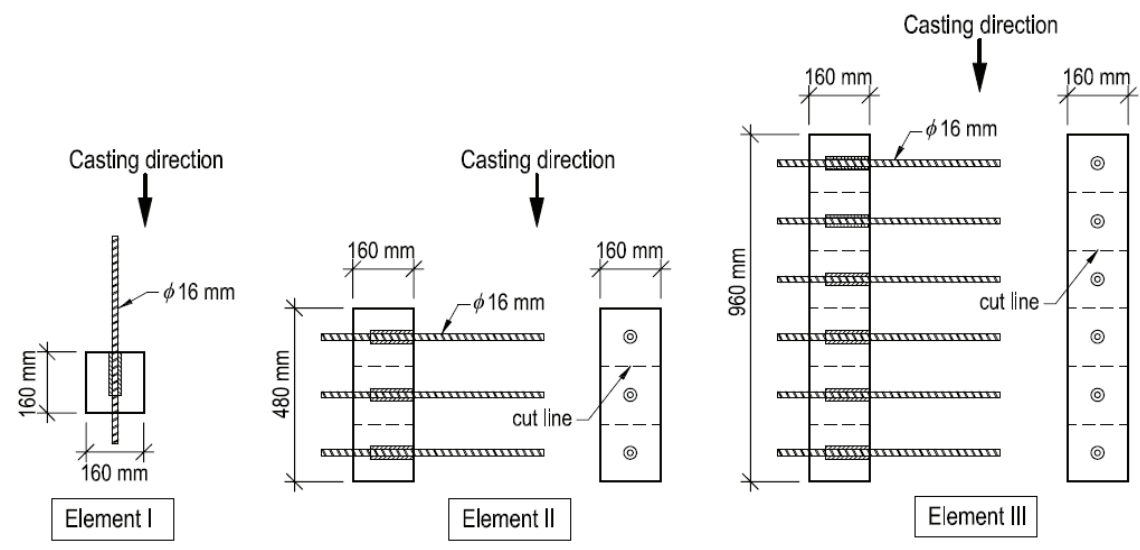

Fig. 3. Test speciments 
The bond behaviour was tested on modified RILEM-specimens. Divergent from RILEM-specimen the bond length was reduced to 2,5 $\mathrm{x}$ the rebar diameter, because of the high transferable bond forces in HPC. With larger bond length the forces will be so high, that the reinforcing steel will yield and pull-out failure would not occur.

The type III specimen was made in all the variants of concrete mix, while I and II specimens in two variants of symbols A-5 and B-5. The various elements were prepared in the same way, in a series of 4 elements for a given mixture.

\section{RESULTS OF THE AUTHORS' EXPERIMENTS AND THEIR INTERPRETATION}

The results of experiments run by the authors have been shown in Figures 4-10. Figures 4-6 present a comparison of norm guidelines with the experiments' results.

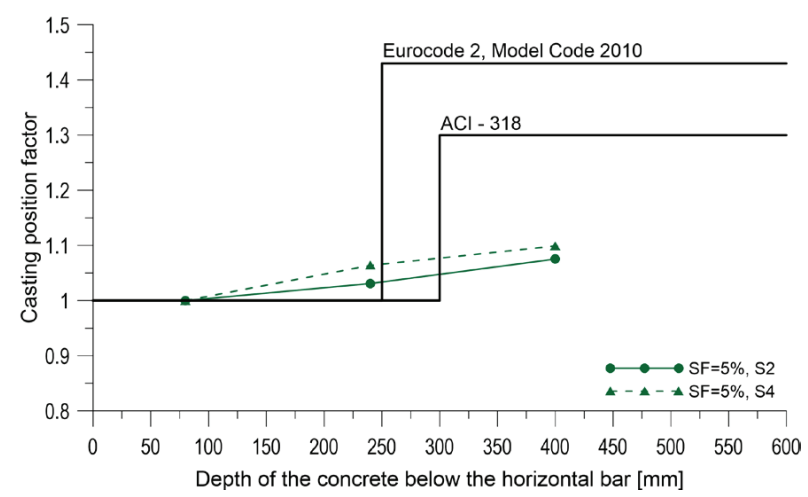

Fig. 4. Casting position factor vs. reinforcement position for elements type II

On the basis of the comparison above it can be concluded that the casting position factor depends on the concrete composition, mix consistency and, mainly, the bar position during concrete placement. The continuous black line indicates the Eurocode 2 [12], Model Code 2010 [14] and ACI Building Code [5] guidelines on the casting position factor. Since the factor in question can be selected for formworks higher than $600 \mathrm{~mm}$ following Eurocode 2 [12] and Model Code 2010 [14] recommendations, the broken black line was used to indicate the curves for the aforementioned recommendations.

Figure 6 presents a comparison between the casting position factor curves and values for normal and high-performance concretes. For normal concrete the upper bars anchorage length should be even doubled to reach the bond strength as for the lower bars. The main factor affecting bond reduction in normal concrete is concrete mix consistency. This suggests that for higher consistency classes the difference in bond conditions between normal and high-performance concretes will be even larger. 


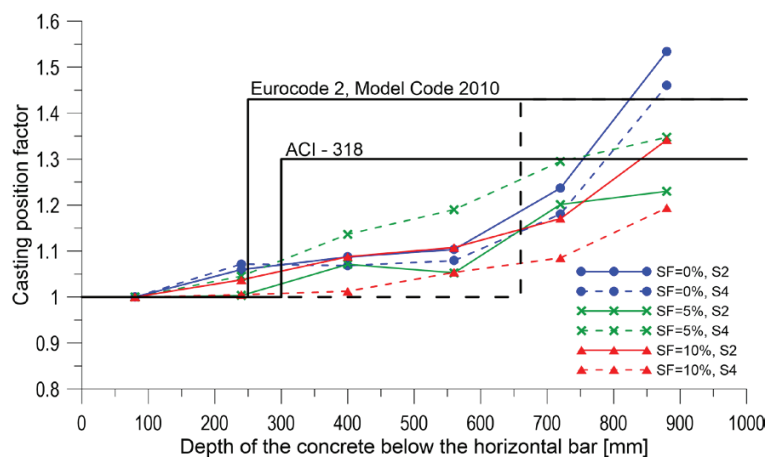

Fig. 5. Casting position factor vs. reinforcement position for elements type III

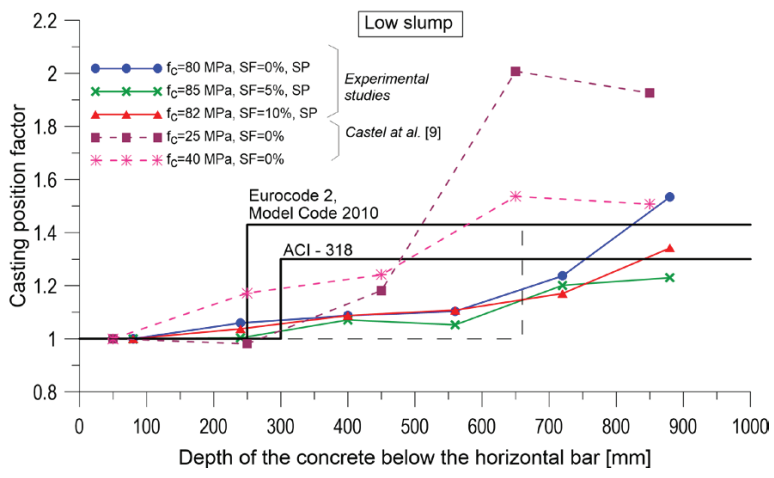

Fig. 6. Casting position factor vs. their position in element for normal and high-performance concrete (consistency class S2)

The effect of element height on bond has been eliminated in reference specimen type I. The bar was oriented parallel to concrete placement direction and the pull-out test was performed in the opposite direction, the result of which was that concrete sedimentation and settlement did not cause bond stress reduction. This element, then, can be regarded as a determinant of "good" bond conditions.

The ratio between the value of bond obtained for the reference formwork type I and the value of the bond of bottom bars of element type III (concrete with 5\% addition of silica fume) was 0,92 in the case of consistency class S2 and 0,90 for consistency S4. When these values for the other mixes are adopted, the bond conditions change at the element height will look as shown in Figure 7. In the case of element type II $(480 \mathrm{~mm})$ the bond increase shown was only slight and did not exceed the value of result scatter.

The results analysis has proved that the height of a reinforced concrete element is significant in selecting bond conditions. It also justifies the pertinence of Eurocode 2 
[12] and Model Code 2010 [14] recommendations as to the estimation of bond conditions, in which such differentiation was introduced. The aforementioned recommendations offer the possibility reducing the zone of "poor" bond conditions for high elements (higher than $600 \mathrm{~mm}$ ).

There are two approaches to the casting position factor. In one the relationship between a linear change in the factor and the reinforcing bar distance from the form bottom $-z$ is given. Such approach allows designers to determine the value of the factor for each value of $z$. In the other approach the change of the value of the factor is abrupt at the element height.

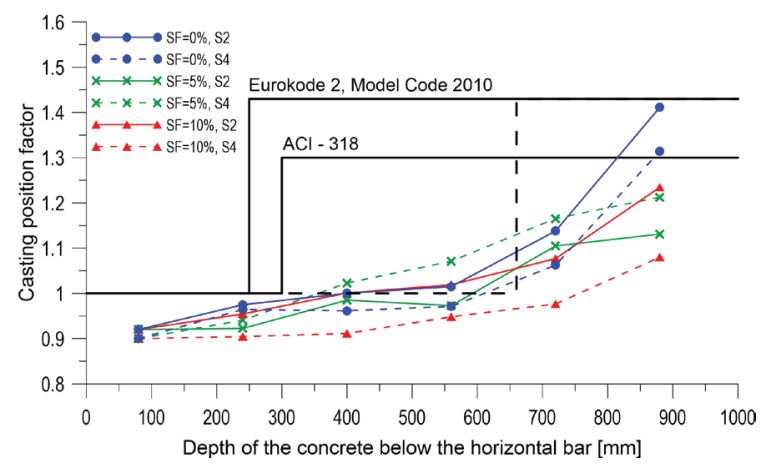

Fig. 7. Casting position factor vs. their position in elements type III relative to reference specimen

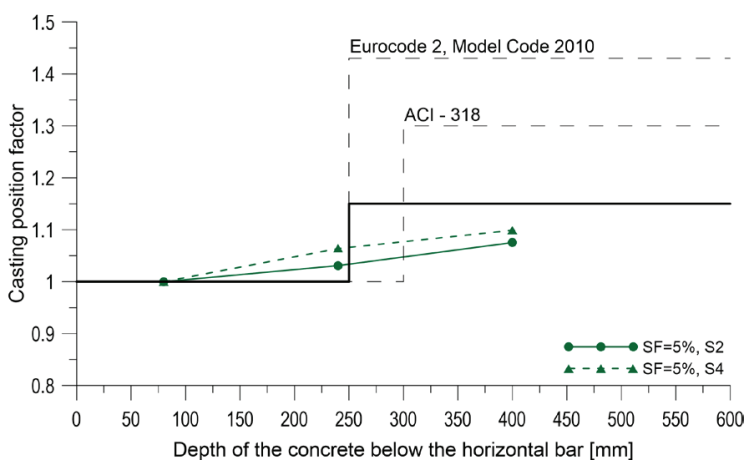

Fig. 8. Proposition of changes in the value of the casting position factor vs. their position in elements of height up to $600 \mathrm{~mm}$ made from high-performance concrete

Figure 8 presents a change of bond conditions at the height of element II ( $480 \mathrm{~mm})$ and a proposition of an abrupt change of the casting position factor. The values of the factor for elements to the height of $600 \mathrm{~mm}$ made from high-performance concrete with silica fume addition have been summarised in Table 3. 
Table 3.

Proposition of the values of the casting position factor for elements of up to $600 \mathrm{~mm}$

\begin{tabular}{|c|c|}
\hline $\begin{array}{c}\text { Concrete layer beneath } \\
\text { bar [mm] }\end{array}$ & $\begin{array}{c}\text { HPC with addition of } \\
\text { silica fume }\end{array}$ \\
\hline$\leq 250$ & 1,0 \\
\hline $250 \div 600$ & 1,15 \\
\hline
\end{tabular}

Figure 9 and 10 illustrate a change in bond conditions at the height of formwork III difference between the maximum values of the factor for HPC with the addition of and with no addition of silica fume, the recommended way of determining the casting position factor was given separately for these two types of concrete.

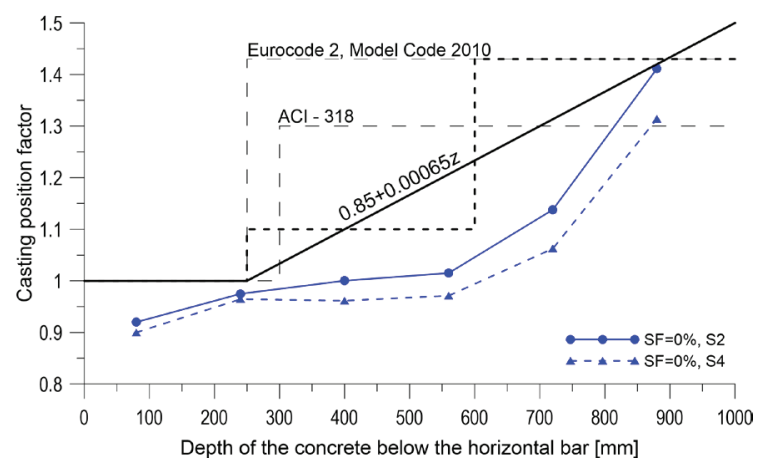

Fig. 9. Proposition of changes in the value of the casting position factor for elements of height of $600 \div 1000$ $\mathrm{mm}$ made from HPC with no silica fume (SF)

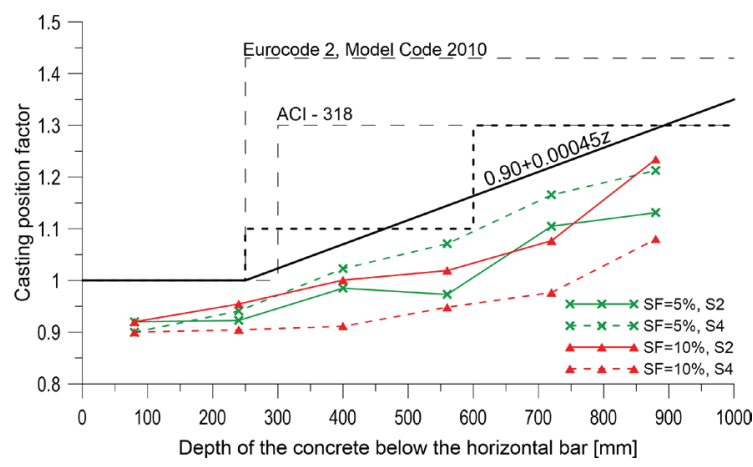

Fig. 10. Proposition of changes in the value of the casting position factor for elements of height of $600 \div 1000 \mathrm{~mm}$ made from HPC with addition of silica fume (SF) 
For formworks of height between 600 and $1000 \mathrm{~mm}$ the fundamental anchorage length should be multiplied by the casting position factor, which is:

- for high-performance concrete with no silica fume addition: 0,85+0,00065 z,

- for high-performance concrete with the addition of silica fume: $0,90+0,00045 z$, where:

$z$ - concrete layer thickness beneath the reinforcing bar in millimetres, $z$ is in the range

250 to $1000 \mathrm{~mm}$.

The idea of an abrupt change in the casting position factor for elements of height from 600 to $1000 \mathrm{~mm}$ has been given in Table 4 .

Table 4.

Proposition of the values of the casting position factor for elements of height of $600 \div 1000 \mathrm{~mm}$

\begin{tabular}{|c|c|c|}
\hline \multirow{2}{*}{$\begin{array}{c}\text { Concrete layer beneath } \\
\text { bar [mm] }\end{array}$} & Type of HPC \\
\cline { 2 - 3 } & No addition of silica fume & $\begin{array}{c}\text { With addition of silica } \\
\text { fume }\end{array}$ \\
\hline$\leq 250$ & 1,0 & 1,0 \\
\hline$>250 \mathrm{i} \leq 600$ & 1,1 & 1,1 \\
\hline$>600 \mathrm{i} \leq 1000$ & 1,43 & 1,3 \\
\hline
\end{tabular}

In Eurocode 2 [12] and Model Code 2010 [14] recommendations the factor for bond conditions and bar position during concrete placement is recommended, which is an inverse of the casting position factor presented earlier. Using the terminology of Eurocode 2 [12] and Model Code 2010 [14] a proposition of an abrupt change of factor for elements of height of up to $600 \mathrm{~mm}$ has been presented in Table 5 .

Table 5.

Proposition of the values of the bond conditions and the position of the bar during concreting factor values for elements of up to $600 \mathrm{~mm}$

\begin{tabular}{|c|c|}
\hline $\begin{array}{c}\text { Concrete layer beneath } \\
\text { bar }[\mathrm{mm}]\end{array}$ & $\begin{array}{c}\text { HPC with addition of } \\
\text { silica fume }\end{array}$ \\
\hline$\leq 250$ & 1,0 \\
\hline $250 \div 600$ & 0,87 \\
\hline
\end{tabular}

For elements of height between 600 and $1000 \mathrm{~mm}$ the design value of the ultimate bond strength should be multiplied by bond conditions and the position of the bar during concreting factor which is:

- for high-performance concrete with no addition of silica fume: $1,1-0,00045 \mathrm{z}$,

- for high-performance concrete with the addition of silica fume: $1,1-0,00035 \mathrm{z}$. 
A proposition of an abrupt change of the bond conditions and the position of the bar during concreting factor value for elements of height between 600 and $1000 \mathrm{~mm}$ has been shown in Table 6.

Table 6.

Proposition of the values of the bond conditions and the position of the bar during concreting factor value for elements of height of $600 \div 1000 \mathrm{~mm}$

\begin{tabular}{|c|c|c|}
\hline \multirow{2}{*}{$\begin{array}{c}\text { Concrete layer beneath } \\
\text { bar [mm] }\end{array}$} & No addition of silica fume & $\begin{array}{c}\text { With addition of silica } \\
\text { fume }\end{array}$ \\
\cline { 2 - 3 } & 1,0 & 1,0 \\
\hline$\leq 250$ & 0,9 & 0,9 \\
\hline$>250 \mathrm{i} \leq 600$ & 0,7 & 0,77 \\
\hline$>600 \mathrm{i} \leq 1000$ & & \multicolumn{2}{|c|}{ Type of HPC } \\
\hline
\end{tabular}

Bond stress reduction related to reinforcement position can be accounted for by several reasons:

1. Beneath horizontally embedded reinforcement particles of lower density accumulate, which is followed by an increase in the amount of water (increase of w/c) and air flow under the reinforcement. In consequence, a layer of weaker concrete of high porosity is formed.

2. As a result of concrete slipping along the bar and fresh concrete mix settlement, the bar concrete cover deteriorates, which means bond efficiency reduction.

3. In the case of vertically oriented reinforcement there occurs a big quality difference between the concrete above and beneath the reinforcement ribs. The operation of ribs has a retarding effect on concrete sedimentation and settlement. As a result of these processes the concrete-reinforcement bond is better when the steel wedge is subjected to pull-out in the direction opposite to concrete placement.

\section{Conclusions}

The results of experiments performed prove that in both high-performance and normal concretes at the element height there are different bond conditions. The physical bases of this effect are related to a special form of bleeding and settlement of fresh concrete mix. Nevertheless, the modified microstructure and different mechanical properties of HPC result in the fact that the maximum differences of bond between the zone of "good" and "poor" bond conditions are much smaller than in normal concrete. The results for bond stress reduction obtained for specimens $960 \mathrm{~mm}$ in height depended on the composition of concrete mix and were between 17 and $35 \%$. In the case of normal concrete the maximum bond difference obtained in the identical tests was between 35 and $50 \%$. 
What decides of the value of the casting position factor is not only the bar position in the element. The other equally important parameters affecting the value of this factor are the mechanical properties of concrete, its microstructure resulting from adequate additives and agents as well as the element's total height. The experiments proved that it is advisable to determine the bond conditions quality factor separately for high-performance and normal concrete.

The norm rules valid quote principles and recommendations which are based on experiments performed over thirty years ago. Some do not correspond with the stateof-the art science and advancement of reinforced concrete structures any longer. This refers in particular to concretes of new generation, including high-performance concrete. This state of affairs can be attributed to a traditional, conservative character of the norms and design recommendations together with the complexity of the problem of bond.

Adopting one level as a boundary between "good" and "poor" bond conditions is not justified by experimental tests. The results of experiments presented prove that regardless of HPC mix composition and consistency, the value of the casting position factor does depend on the thickness of concrete layer beneath the reinforcing bar.

The results of experiment performed by the authors show a comparison of the bond between concrete and bars at different heights in the element versus concrete-lower bars bond. The analysis proved that "good" bond conditions are a relative concept, dependent on, among other things, element height. The higher the element the better the concrete to lower bars bond. Consequently, elements of considerable height (higher than $600 \mathrm{~mm}$ ) demonstrate a bigger difference between concrete-upper bars bond and concrete-lower bars bond.

\section{REFERENCES}

1. ACI Committee 318, Building Code Requirements for Reinforced Concrete (ACI 318-51), American Concrete Institute, 1951.

2. ACI Committee 318, Building Code Requirements for Reinforced Concrete (ACI 318-71), American Concrete Institute, 1971.

3. ACI Committee 318, Building Code Requirements for Reinforced Concrete (ACI 318-77), American Concrete Institute, 1977.

4. ACI Committee 318, Building Code Requirements for Reinforced Concrete (ACI 318-89), American Concrete Institute, 1989.

5. ACI Committee 318, Building Code Requirements for Structural Concrete (ACI 318-08), American Concrete Institute, 2008.

6. ACI Committee 408, Suggested Development, Splice and Standard Hook Provisions for Deformed Bars in Tension, Concrete International 1, 7, 1979.

7. B. Brettmann, D. Darwin, R. Donahey, Effect of Superplasticizers on Concrete-Steel Bond Strength, SL Report No. 84-1, University of Kansas Center for Research, 1984.

8. B. Brettmann, D. Darwin, R. Donahey, Bond of Reinforcement to Superplasticized Concrete, ACI Journal, 83, 1, 98-107, 1986. 
9. A. Castel, T. Vidal, K. Viriyametanont, R. Francois, Effect of Reinforcing Bar Orientation and Location on Bond with Self-Consolidating Concrete, ACI Structural Journal, 103, 4, 559-567, 2006.

10. A. P. Clark, Comparative Bond Efficiency of Deformed Concrete Reinforcing Bars, Journal of Research, 5, 37, 399-407, 1947.

11. P. DyвEx, The influence of the composition and properties of high-performance concrete on the bond strength of reinforcement bars, Doctoral Thesis, Cracow University of Technology, 2013.

12. Eurocode 2, Design of concrete structures-Part 1-1: General Rules, and Rules for Buildings, UNIENV 1992-1-1, European Committee for Standardization, 2008.

13. В. S. HAmad, R. A. АкIK, Role of casting position on bond strength of reinforcement in eccentric pullout silica fume concrete specimens, Materials and Structures, 34, 3, 163-171, 2001.

14. FIB, Bulletin No. 65, Model Code 2010 - Final draft, Volume 1, 2012.

15. K. Holschemacher, F. Dehn, D. Weisse, Influence of the Rebar Position on the Bond Behaviour in Hight-Strenght Concrete, Leipzing annual civil engineering report 7, 135-144, 2002.

16. P. R. Jaunty, D. Mitchell, M. S. Mirza, Investigation of Top Bar Effects in Beams, ACI Material Journal, 85, 3, 251-257, 1988.

17. J. O. Jirsa, J. E. Breen, Influence of Casting Position and Shear on Development and Splice Length - Design Recommendation, Research Report No. 242-3F, Center for Transportation Research, The University of Texas at Austin, 1981.

18. J. J. Luke, B. S. Hamad, J. O. Jirsa, J. E. Breen, The Influence of Casting Position on Development and Splice Length of Reinforcing Bars, Research Report No. 242-1, Center for Transportation Research, Bureau of Engineering Research, University of Texas at Austin, 1981.

19. J. J. Pędziwiatr, L. J. Jankowski, Some results of experimental researches on bond in reinforced concrete members, Archives of Civil Engineering, 53, 1, 37-55, 2007.

20. RILEM/CEB/FIP, Technical recommendations for the testing and use of construction materials, E\&FN Spon, U.K., 1983. 
